\title{
Green techniques for extraction of bioactive carbohydrates
}

6

A. Mena-García, A.I. Ruiz-Matute, A.C. Soria, M.L. Sanz*

7 Instituto de Química Orgánica General (CSIC). Juan de la Cierva 3, 28006 Madrid

8

(Spain)

9

10

11

12

13

14

15

16

17

18

$19 *$ Corresponding author: mlsanz@iqog.csic.es 


\section{Abstract}

22 Novel methodologies for the improved extraction of bioactive carbohydrates that fulfill the principles of green chemistry have been reviewed in this manuscript. As an alternative to conventional water extraction methods, advantages of the use of new green solvents such as ionic liquids and deep eutectic solvents have been discussed. Recent applications of advanced techniques such as ultrasound-assisted extraction (UAE), microwave-assisted extraction (MAE), pressurized liquid extraction (PLE), supercritical fluid extraction (SFE) and enzyme-assisted extraction (EAE) have also been revised. Special attention has been paid to those procedures based on the combination of several of these techniques which provide a better performance [e.g. ultrasound-microwave-assisted extraction (UMAE)] or show an improved selectivity [e.g. microwave-assisted aqueous two-phase extraction (MAATPE), microwaveassisted enzymatic extraction or enzymolysis-ultrasound-assisted extraction (MAEE or EUAE), etc.]. Finally, future perspectives regarding the possible application of these new eco-friendly methodologies at industrial scale together with the advances required to that aim are presented.

Keywords: bioactive carbohydrates, ionic liquids (ILs), deep eutectic solvents (DES), pressurized-liquid extraction (PLE), supercritical fluid extraction (SFE), microwaveassisted extraction (MAE), ultrasound-assisted extraction (UAE), enzyme-assisted extraction (EAE). 


\section{Introduction}

Carbohydrates are important components of the diet which can be naturally present in

47 foods (i.e. milk, fruits, legumes, etc.) or intentionally added during their processing and

48 preparation. As food ingredients, carbohydrates can be either extracted from natural

49 products or be chemically or enzymatically synthesized. These compounds provide not only organoleptic characteristics and nutritional value, but also functional properties beneficial for human health. In this sense, some oligosaccharides (OS) have shown prebiotic and antiadherent properties [1]; iminosugars have inhibitory activity against glycosidases [2]; inositols can be used for treating conditions associated with insulin resistance (diabetes mellitus, obesity, atherosclerosis, etc.) [3] and polysaccharides present different activities related to the prevention of gastrointestinal disorders, the reduction of blood cholesterol level, the slowdown of sugar absorption into the blood, etc. [4].

Complex mixtures of carbohydrates with different monomeric units, glycosidic linkages and polymerization degree are usually found in natural sources together with other constituents such as proteins, lipids, amino acids, etc. Traditional methods for extraction of carbohydrates are mainly based on solid-liquid extraction (SLE) and liquid-liquid extraction (LLE). However, these procedures are not selective for specific bioactive carbohydrates and other interfering compounds, present either in natural or synthesized products, can also be coextracted. Therefore, an additional fractionation step is crucial not only to obtain fractions enriched in target bioactive carbohydrates, but also to make easier their structural characterization by using different analytical techniques.

67 However, this step is not straightforward considering the similar structure of carbohydrates and their different abundances in these complex mixtures. Although classical techniques based on the use of membranes (ultrafiltration, nanofiltration, 
diafiltration, etc.) or chromatographic techniques (size exclusion chromatography, ion exchange chromatography, etc.) are still used to this aim, they are time consuming and the yields and/or the purity of the resulting product are relatively low [5]. Therefore, enhanced and environmentally friendly solvent-based extraction techniques, which provide higher yields and a selective extraction of bioactive carbohydrates, have emerged in the last years. The present manuscript aims to provide insight into the most outstanding developments of these techniques, mainly published in the 2013-2019 period; recent applications in food science have also been reviewed and discussed.

\section{New green solvents}

Water is generally used as solvent for carbohydrate extraction; however, and despite it is the greenest and the most economic extractant, it is not selective for carbohydrates and several other compounds, even interferents with their bioactivity, might be coextracted. Organic solvents, mainly alcohols, have been traditionally used to selectively precipitate some target carbohydrates, while the others remain dissolved in the extraction mixture (e.g. separation of ketoses from non-bioactive aldoses is possible using methanol, ethanol and hydroalcoholic mixtures [6]). However, these methods usually require high solvent volumes and the successful of the process greatly depends on experimental conditions and carbohydrates considered.

88 In recent years, the use of ionic liquids (ILs) for the extraction and fractionation of bioactive carbohydrates has been proposed. ILs are organic salts constituted by organic cations such as imidazolium, pyridinium, pyrrolidinium, etc., and organic or inorganic anions such as chloride, dicyanamide, trifluoroacetate, etc., with melting points lower than $100{ }^{\circ} \mathrm{C}$. They are considered as green solvents taking into account their unique properties such as negligible vapor pressure over a wide temperature range, high 
94 thermal stability and high viscosity. In addition to the improved yields and 95 productivities described for several industrial processes based on the use of ILs, these solvents can also be recovered and final products with only traces of residual solvent can be obtained. This recyclability is an additional benefit that has contributed to promote their use and the number of applications of ILs in the last years is on the rise [7].

Studies on the solubility of both high and low molecular weight carbohydrates in ILs have been extensively conducted in the last years [8-10], although applications of these solvents for the extraction or fractionation of these compounds from natural sources are still scarce. Considering the different solubility of carbohydrates in ILs, CarreroCarralero et al. [11] effectively fractionated bioactive ketoses, i.e. lactulose and tagatose, from their corresponding aldoses, lactose and galactose, using methylimidazolium ILs. Moreover, as an example of application, a lactose isomerization mixture, containing lactulose, galactose, glucose and the unreacted lactose, was enriched in the ketose by using 1-ethyl-3-methylimidazolium dicyanamide ([EMIM][DCA]. Methylimidazolium ILs have also been used for the selective fractionation of added-value polyols (acyclic sugar alcohols and inositols) from other low molecular weight carbohydrates in binary mixtures [12].

112 Due to the lack of volatility of ILs, the recovery of carbohydrates dissolved into these solvents is a task worthy of consideration. To this aim, several methodologies have been proposed such as column chromatography, supercritical $\mathrm{CO}_{2}$ extraction, antisolvent effect, etc. [13], although none of them can be considered of general application. Carrero-Carralero et al. [11] proposed an activated charcoal-based treatment to recover 117 lactulose dissolved in [EMIM][DCA]; this step, besides allowing the carbohydrate recovery from the solvent, could also facilitate the recycling of the IL. Figure 1 shows 
the general scheme proposed for the synthesis, fractionation, and recovery of lactulose using [EMIM][DCA] and activated charcoal.

Nevertheless, although ILs have been proposed as a green alternative to harmful organic solvents and several studies have already reported that very low concentrations of ILs do not exhibit a toxicological effect [14], further research is still required to fully assure their safety. Moreover, individual studies have to be carried out as IL potential toxicity is highly dependent on the IL considered and intended application [15]. This is particularly important in the food field where no legislation for the use of ILs is currently available [7]

Thus, in the last years, deep eutectic solvents (DES), and especially natural deep eutectic solvents (NADES), have been introduced as eco-friendly and sustainable alternative media. They are low-cost eutectic mixtures with physical and chemical properties comparable to ILs [16] and are prepared by combining hydrogen bonding acceptors (HBAs) and hydrogen bonding donors (HBDs) to form eutectic mixtures. DES are easier to synthesize than conventional ILs, stable, cost-competitive, etc., and most of them are environmentally-friendly [17]. Until now, DES have been proposed to dissolve polysaccharides such as cellulose, hemicellulose, starch, chitin and lignin for biomass processing $[18,19]$. In these studies, differences in solubility among the different polysaccharides have been detected. As an example, lignin was highly soluble (up to $14.9 \%$ at $100{ }^{\circ} \mathrm{C}$ ) in maleic acid/proline (1:3), while the solubility of cellulose was negligible in this solvent [20]. These studies open new lines of research based on the application of DES for bioactive carbohydrate extraction and fractionation.

\section{Advanced extraction techniques}


142 In order to overcome major shortcomings of conventional SLE (hot or boiling water methods), mainly associated with the use of high temperatures and extended extraction

144 times, low efficiency, degradation of thermolabile polysaccharides, etc., advanced extraction techniques such as microwave-assisted extraction (MAE), ultrasound-assisted extraction (UAE), pressurized liquid extraction (PLE), supercritical fluid extraction (SFE) and enzyme-assisted extraction (EAE) have emerged during the last decades for improved green extraction of bioactive carbohydrates. Some recent application examples of these techniques for the extraction/fractionation of these compounds are presented in Table 1.

\subsection{Ultrasound-assisted extraction}

In UAE, low frequency (16-100 kHz) and high power (typically in the range 80-200 W) ultrasound (US) waves are used to provide disruption of cell walls that facilitate the release of target analytes, to accelerate diffusion and to increase mass transfer and to allow a greater penetration of solvents into the US-radiated matrix [21]. All these effects, mainly associated with the cavitation phenomenon, typically provide inexpensive, simple and efficient (higher extraction yield and shorter extraction time) methods for extraction of carbohydrates (mainly polysaccharides) from different vegetable matrices and by-products (Table 1).

Regarding UAE of bioactive polysaccharides, most of applications have focused on the development of methods based on the use of ultrasonic baths provided with temperature control and using water as extraction solvent. For every sample, optimization (usually by means of an experimental design) of operating conditions (liquid:solid ratio, extraction temperature and time, US power) is carried out as it plays a significant role on both, the chemical composition and bioactivity of the obtained products [22,23]. As 
an example, Lin et al. [24] evaluated the effect on structural composition and bioactivity of polysaccharides extracted by UAE from Ziziphus jujuba Mill var. spinosa seeds. Under optimized conditions $\left(26.3 \mathrm{~mL} \mathrm{~g}^{-1}, 52.5^{\circ} \mathrm{C}, 21.2 \mathrm{~min}, 134.9 \mathrm{~W}\right)$, UAE provided similar (1.05 vs $0.93 \%)$ extraction yields to hot water extraction $\left(7.5 \mathrm{~mL} \mathrm{~g}^{-1}, 70^{\circ} \mathrm{C}, 2 \mathrm{x} 3\right.$ hours); however, UAE extracts showed higher bioactivity.

Recently, Pawlaczyk-Graja et al. [25] compared different alkaline $(0.1 \mathrm{M} \mathrm{NaOH})$ methods, including cold extraction, hot extraction, MAE and UAE, to obtain polyphenolic-polysaccharide conjugates from Fragaria vesca L. leaves. The use of an additional source of energy supporting extraction (i.e., UAE and MAE) gave rise to significant differences in polysaccharide structures. Moreover, UAE extracts with the highest anticoagulant activity were obtained in an ultrasonic homogenizer provided with a titanium tip of $25.4 \mathrm{~mm}$ operating at $20 \mathrm{kHz}, 60 \mathrm{~W}, 40 \mathrm{~min}$ at $25^{\circ} \mathrm{C}$.

Ultrasound-assisted aqueous two-phase extraction (UAATPE) has also been reported as a novel and improved liquid-liquid method for the extraction of polysaccharides and glycosides from different natural sources [26,27]. In this technique, based on the selectivity of a biphasic system constituted by polymer or salt saturated solutions, the selection of the particular ATP system greatly determines the extraction yield and purity of extracts. Ji et al. [28], using a $29 \%$ ethanol/15\% ammonium sulfate as a multiphase solvent, reported extraction yields of antioxidant polysaccharides from Z. jujuba cv. jujube polysaccharides as compared to UAE and hot water extraction, but it also simultaneously separated the ethanol-soluble from the water-soluble polysaccharides. Therefore, UAATPE is shown as a promising green and economical technology with high potential for extraction of polysaccharides at industrial scale. 
191 The development of DES-based UAE approaches as green, fast and effective 192 methodologies for polysaccharide extraction has attracted considerable interest in the 193 last years. As reported by Zhang \& Wang [29], different types of choline chloride-DES 194 as well as UAE operating parameters were evaluated for the extraction of 195 polysaccharides from Dioscorea opposite Thunb. The optimal extraction conditions 196 (choline chloride-1,4-butanediol (1:4) with 33\% water content, $30 \mathrm{~mL} \mathrm{~g}^{-1}, 94^{\circ} \mathrm{C}$ and 45 197 min) provided higher extraction yields than those of hot water extraction and water based-UAE (16 vs 10 and 12\%, respectively).

\subsection{Microwave-assisted extraction}

Microwave (MW) heating is based on the direct interaction of electromagnetic waves (typically $2.45 \mathrm{GHz}$ ) with polar solvent molecules through dipole rotation and ionic conduction. This heating mechanism allows the breakage of tissues and cells releasing bioactive compounds from the cell walls or plasma membranes [30] and, therefore, improving extraction yields and reducing time and solvent volume as compared to conventional extraction techniques. Furthermore, due to its operational simplicity and low cost, industrial scale-up approaches have been developed [31].

MAE of carbohydrates has been mainly focused on the extraction of bioactive polysaccharides from different fruits, vegetables and algae [32-34], and to a lesser extent, to obtain bioactive OS, inositols and glucosinolates [34-36]. MAE conditions for some of these recent applications are summarized in Table 1. Water is usually chosen as the most appropriate solvent, due to the good water solubility of

212 carbohydrates and its high dipolar moment which improves MW heating mechanism. In 213 some cases, water is used under strongly acidic conditions; however, special care should be taken to avoid the potential hydrolysis of polysaccharides to short chain molecules, 
which could affect (either positively or negatively) the extraction yields $[32,33]$. The sequential use of UAE and MAE has also been evaluated for the extraction of pectin from pomelo peels, concluding that this combination allowed an improvement on the carbohydrate yield (36.3\%) over the use of sole MAE and UAE $(27.6 \%$ and $14.2 \%$, respectively) [37].

In order to improve the performance of conventional and advanced methods for extraction of bioactive carbohydrates, ultrasound-microwave-assisted extraction (UMAE) has been recently developed. Thus, a new and commercially available UMAE equipment has been used to extract prebiotic OS from lotus (Nelumbo nucifera Gaertn.) seeds [38]. The extraction yields through UMAE (11.1\% in $5.42 \mathrm{~min})$ was increased by 77, 18 and 27\% over warm extraction, UAE and MAE, respectively, whereas extraction time was shortened as much as $12 \%$ as compared to conventional warm water extraction. This technique has also been applied to obtain arabinoxylans from corn bran under alkali conditions [39]. In this work, ultrasonic-microwave synergetic time (25 min), ultrasonic power $(500 \mathrm{~W})$, solvent-to-material ratio $\left(30 \mathrm{~mL} \mathrm{~g}^{-1}\right)$ and concentration of sodium hydroxide $\left(0.30 \mathrm{~mol} \mathrm{~L}^{-1}\right)$ were optimized to achieve the highest yields $(27.78 \pm 0.17 \%)$, avoiding polysaccharides degradation.

Microwave hydrodiffusion and gravity $(\mathrm{MHG})$ is a relatively new technique mainly used for extraction of essential oils, but which has recently been considered for extraction of bioactive compounds [36]. As an example, in this technique microwave heating has been used to simultaneously allow the solvent-free extraction of bioactive compounds (glucosinolates, polyphenols and amino acids) and to provide a dried residue (up to $12 \%$ moisture) rich in polysaccharides and proteins from broccoli byproducts [34]. However, MHG is limited to the extraction of soluble low molecular weight molecules from fresh matrices, excluding low water content or dry matrices. 
240 Recently, surfactant and microwave-assisted extraction (S-MAE) has been used for 241 pectin extraction from orange peels [32]. Depending on the concentration of surfactant, 242 micelles capable of establishing chemical and physical interactions with 243 polysaccharides, among other hydrophilic substances, can be formed to favour the 244 extraction. In this case, MAE yield of pectin (28\%) was improved by the addition of the 245 surfactant Tween-80 $\left(8 \mathrm{~g} \mathrm{~L}^{-1}, \mathrm{w} / \mathrm{v}\right)$ by $17 \%$.

246 Although MAE lacks enough selectivity to be used for carbohydrate fractionation on its own, several studies have evaluated the use of different solvents (e.g. different alcohol:water mixtures [35]) to selectively extract bioactive carbohydrates. However, an additional step after MAE such as yeast treatment [34], enzymatic treatment [40] or precipitation by ethanol addition [39] is usually required. Therefore, new approaches for enhancing the selectivity of the extraction such as microwave-assisted aqueous twophase extraction (MAATPE) are being developed. For example, a rapid and one-step MAATPE procedure has been proposed for the simultaneous extraction and fractionation of polysaccharides from Semen cassiae seeds. As compared to heating solvent extraction and UAE, MAATPE under optimized conditions $(25.4 \%$ ethanol/22 $\%$ ammonium sulfate, $\left.80{ }^{\circ} \mathrm{C}\right)$ exhibited the highest extraction yield $(13.3 \%$ total polysaccharide; $4.5 \%$ homopolysaccharides and $8.8 \%$ heteropolysaccharides) in the shortest time (20 min) (Figure 2) [40]. Polysaccharides from Gentiana scabra stems

259 have also been extracted by MAATPE using $21.73 \%$ ethanol and $23.27 \% \mathrm{NaH}_{2} \mathrm{PO}_{4}$ at $95{ }^{\circ} \mathrm{C}$ for $5.8 \mathrm{~min}$. This technique provided an improved performance over MAE, UAE and heat reflux extraction, giving yields as high as $16 \%$ for total polysaccharides and purities of $78 \%$ for water-soluble polysaccharides [41].

\subsection{Pressurized liquid extraction}


264 PLE is an automated extraction technique based on the use of elevated temperatures and 265 high enough pressures to keep the solvents at liquid state above their atmospheric 266 boiling point. These conditions allow the increase of solubility and mass transfer rates 267 which enhance solvent diffusivity and, therefore, improve extraction kinetics [42]. 268 When water is used under its critical point, this green technique is also referred as 269 subcritical water extraction (SWE) or pressurized hot water extraction (PHWE).

PLE has been widely applied for the extraction of cyclitols from several plants and herbs like alfalfa [43], purple tansy [44], goldenrods [45], pine nuts [46], etc., and it has also been proposed for the extraction of prebiotic oligosaccharides, specifically 273 fructooligosaccharides (FOS) from Brazilian ginseng [47]. In general, under optimized PLE conditions (see Table 1), higher extraction yields and a noticeable reduction of extraction time and solvent volume compared with SLE was achieved. This technique has also been proposed for the simultaneous extraction of inositols and inuline from artichoke bracts [34]. In this last study, a comparison between PLE and MAE was performed. Although PLE was appropriate for the extraction of these bioactive carbohydrates, cyclitol yields were higher by MAE (12 vs $78 \mathrm{mg}$ dry sample), whereas inulin was better extracted by PLE (185 vs $96 \mathrm{mg} \mathrm{g}^{-1}$ dry sample). However, these conclusions cannot be extrapolated as a different behavior can be observed depending on the sample matrix and the carbohydrates to be extracted. In this sense, Smiderle et al. [48] observed similar yields in the extraction of $\beta$-glucans from two mushroom species by PLE (10-40\%) and MAE (10-34\%), although both techniques provided higher polysaccharide yields than hot water extractions (7-16\%).

Ultrasound-enhanced subcritical water extraction (USWE) joins the effects of ultrasonic waves and subcritical water, giving rise to a dynamic extraction process. The efficiency of this technique over SWE has been evaluated by Chao et al. [49] for the extraction of 
polysaccharides from $L$. barbarum L. In figure 3 the individual effects of temperature, time, liquid-to-solid ratio and extraction pressure are shown for both treatments, showing the better performance of USWE in all cases. After optimization of the mentioned parameters the highest yield (5.73\%) was obtained by USWE at $100{ }^{\circ} \mathrm{C}, 53$ min, liquid-to-solid ratio $26 \mathrm{~mL} \mathrm{~g}^{-1}$ and $160 \mathrm{~W}$.

As well as for MAE and UAE, water is the solvent generally used for the green PLE extraction of carbohydrates as it is inexpensive, non-toxic, environmentally friendly and with tunable physicochemical properties depending on the operation conditions. However, the possibility of undesired reactions taking place in aqueous or hydroorganic media, or the coextraction of interferences affecting the selectivity of the extraction, particularly at the high temperatures required for several applications, should also be taken into account when using water as extractant $[50,51]$.

Thus, other solvent alternatives have been considered to be used for carbohydrate extraction by PLE. Saravana et al. [52] have recently proposed the use of a DES to extract alginate and fucoidan from brown seaweeds. The use of a choline chloride:glycerol 1:2 DES with $60 \% \mathrm{H}_{2} \mathrm{O}$, aside from the advantages previously mentioned in the development of green procedures, acted as a catalyst and allowed double yields compared to acidified water extraction ( $\mathrm{HCl} ; \mathrm{pH}: 1.3)$ [52].

A limited number of applications have been previously published regarding the fractionation of carbohydrates, mainly due to the low selectivity of this technique on its own. However, Ruiz-Matute et al. [53] successfully used PLE for the extraction and purification of lactulose from a lactose mixture using different ethanol:water mixtures as solvent. This technique provided high lactulose yields (over 78\%) and purities (around $87 \%$ ) and was a good time-saving alternative to conventional procedures. 
313 The combination of PLE with an in-cell packed adsorbent bed of activated charcoal has

314 also been proposed for the separation of monosaccharides from the oligosaccharide 315 fraction of honey. Two consecutive extraction cycles with EtOH: $\mathrm{H}_{2} \mathrm{O}$ (1:99 and 50:50 $316 \mathrm{v} / \mathrm{v}$, respectively) were used to this aim [54]. Purity and yield of target carbohydrates 317 provided by this procedure (73 and 74\% for disaccharides and 8 and $79 \%$ for 318 trisaccharides, respectively) was compared with those achieved by an activated charcoal 319 and a yeast (Saccharomyces cerevisiae) treatments. The removal of monosaccharides was more efficient by yeast treatment, but the recovery of di- and trisaccharides was higher when the optimized PLE method was used.

322 Alternatively, other methodologies based on the combination of a sample pretreatment prior to SWE have also been described for the improved extraction of polysaccharides with bioactive properties. For example, Getachew et al. [55] evaluated how different pretreatments (US, supercritical $\mathrm{CO}_{2}$ or $\mathrm{MW}$ ) affected polysaccharide extraction from coffee spent ground. Depending on the pretreatment used, extraction conditions (temperature and time) could be milder and, thus, less decomposition of polysaccharides took place. In this sense, the highest polysaccharide yield (18.25\%) was obtained by US pretreatment followed by a SWE at $178.85^{\circ} \mathrm{C}, 2 \mathrm{MPa}$ and $5 \mathrm{~min}$.

\subsection{Supercritical fluid extraction}

SFE has mainly been used for the fractionation of low molecular weight carbohydrates.

This technique was successfully employed for the separation of bioactive ketoses from their corresponding aldoses $[6,56]$. The fractionation is based on the different solubility of these carbohydrates in supercritical carbon dioxide $\left(\mathrm{SC}-\mathrm{CO}_{2}\right)$; this process is enhanced by the use of small volumes of polar organic co-solvents such as isopropanol, methanol or alcohol:water mixtures. The total amount of extracted carbohydrates 
strongly depended on the amount (vol. \%) of modifier in the supercritical phase [6]. In

338 this sense, recoveries higher than $75 \%$ of tagatose with $90 \%$ purity $\left(30 \mathrm{MPa}, 80^{\circ} \mathrm{C}, 0.6\right.$

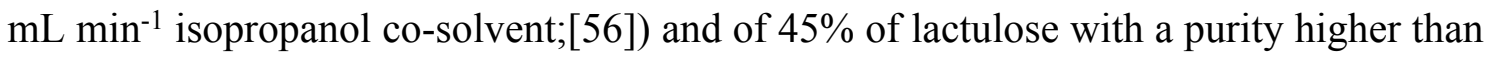

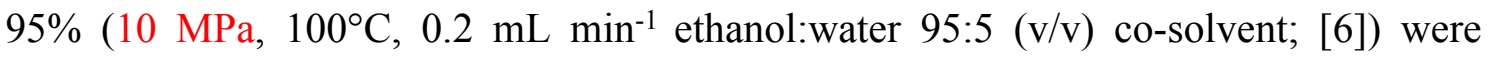
obtained. This technique has also been successfully applied for the selective fractionation of lactulose from different aldoses present in a commercial carbohydrate mixture [57]. An extract with $81 \%$ lactulose and $67 \%$ yield was obtained under optimal conditions (30 $\mathrm{MPa}, 80^{\circ} \mathrm{C}, 0.6 \mathrm{~mL} \mathrm{~min}^{-1}$ ethanol co-solvent).

Carbohydrates can also be fractionated by SFE according to their polymerization degree. In this sense, Montañés et al. [58] selectively fractionated galactooligosaccharides (GOS) in a dairy-based prebiotic ingredient using a two-step SFE process (removal of monosaccharides in the first extraction step and of disaccharides in the second step), using ethanol/water mixtures as co-solvent. The remaining (non-extracted) material mainly comprised prebiotic GOS (75\% purity and 94\% recovery). Moreover, if prebiotic oligosaccharides are produced by enzymatic transglycosylation reactions with complexating reagents (such as sodium aluminate or boric acid), a third SFE step should be considered to remove these agents, leading to a complete fractionation of target carbohydrates (for optimized conditions, see Table 1) [59].

In the last years, some applications of SFE for the extraction of polysaccharides from different natural matrices can be found. Chen et al. [60] used supercritical $\mathrm{CO}_{2}$ for the extraction of polysaccharides from Artemisia sphaerocephala Krasch seeds. Under optimized conditions (extraction pressure of $45 \mathrm{MPa}$, extraction temperature of $45{ }^{\circ} \mathrm{C}$,

360 flow rate of $\mathrm{CO}_{2} 20 \mathrm{~L} \mathrm{~h}^{-1}$, extraction time of $2 \mathrm{~h}$, separation pressure of $10 \mathrm{MPa}$, and separation temperature of $\left.56{ }^{\circ} \mathrm{C}\right)$, polysaccharide yields of $18.59 \%(\mathrm{w} / \mathrm{w})$ were 
obtained. This technique has also been used for the extraction of bamboo (Phyllostachys heterocycla) leave's polysaccharides (PLPs) [61]. The use of ethanol as modifier to improve the solvating power of the $\mathrm{CO}_{2}$ and thus, enhancing the extraction of polar compounds was evaluated. The maximum extraction rate of PLPs $(2.47 \%$, in wt) were obtained under of $2 \mathrm{~h}, 40 \mathrm{MPa}$ with $30 \mathrm{~mL}$ of ethanol modifier at $50{ }^{\circ} \mathrm{C}$.

\subsection{Enzyme-assisted extraction}

EAE is a potential alternative to conventional solvent-based extraction methods, which benefits from the high selectivity, specificity and ability of enzymes to degrade cell walls and membranes. Thus, it enables a better release and more efficient extraction or isolation of the desired carbohydrates or partially degrades target polysaccharides to small fragments in order to ease their extraction [62]. Enzyme technology usually employs aqueous media and it is, therefore, considered a green technique.

EAE of polysaccharides from natural sources has been carried out by using different enzymes such as cellulase, amylase, papain, pectinase and hemicellulose [62-64]. Enzyme specificity and selectivity are influenced by multiple factors such as temperature, time, $\mathrm{pH}$ and enzyme concentration and the use of optimum enzyme reaction conditions is necessary for obtaining the highest hydrolytic activity. In most cases, a combination of enzymes is used in order to extend the range of activities and enhance the efficiency of the extraction [65].

A new strategy to enhance the performance of enzyme technology is the use of EAE in combination with other green extraction techniques such as MAE, UAE and PHWE. These approaches generally provide good extraction efficiencies and the required selectivity in reduced extraction times and by using milder extraction temperatures [62]. For example, enzymolysis-ultrasonic assisted extraction (EUAE) provided a higher yield $(7.1 \%)$ of polysaccharides from corn silk than hot water extraction $(4.6 \%)$. 
Moreover, EUAE procedure gave rise to morphological changes of polysaccharides that improved their antioxidant and anticancer activities [66].

Lee et al. [67] used microwave-assisted enzymatic extraction (MAEE) to extract polysaccharide hydrolysates from Pyropia yezoensis. A 10:1 ratio of substrate to enzyme (carbohydrase) using a MW power of $400 \mathrm{~W}$ during $2 \mathrm{~h}$ were the optimum conditions to efficiently extract these algal polysaccharides.

Enzyme-assisted ionic liquid extraction has also been successfully applied to extract a variety of compounds $[13,62]$, and several studies have focused on the development of IL-tolerant enzymes for the hydrolysis of lignocellulose and cellulose polysaccharides [68]. Recently, the combination of enzyme activity and the extractant power of DES, the so-called DES-based EAE, has been described as a promising alternative strategy for the extraction of polysaccharides from natural matrices due to their higher enzymecompatibility than the cellulose-dissolving ILs. Liang et al. [69] developed a DES-based EAE methodology for the separation and purification of Dendrobium officinale polysaccharides (DOP). Nineteen DES were evaluated to select the most suitable solvent for DOP extraction. The results showed that choline chloride/glycerol-based 403 EAE using cellulose and pectinase was more efficient for DOP extraction $(45 \%)$ than 404 solvent direct extraction (27\%). Moreover, the use of specific enzymes for the selective removal of carbohydrates can also be found in the literature [70,71]. Recently, Aquino et al. [72] obtained fractions 407 enriched in oligosaccharides from goat colostrum (COS) by the enzymatic hydrolysis of 408 lactose by an Aspergillus oryzae lactase prior to a concentration process with 409 membranes. This type of fractionation offers advantages in terms of simplicity and minimum sample handling, as well as the possibility of industrial scaling. However, 
411 during this process the formation of new OS not present in the original sample can also

412 take place by transglycosylation reactions [73].

413 Yeast treatment has also been described to provide high efficiency for the selective and cost-effective fermentation of carbohydrates, with no product dilution or the

415 requirement of nutrient supplementation for yeast growth [74]. In this sense, different 416 strategies using S. cerevisiae, Kluyveromyces lactis or K. marxianus have been used for the purification of GOS and FOS mixtures [74,75]. S. cerevisiae has also been used for the enrichment of legume extracts in inositols [76] and for obtaining an oligosaccharide fraction free of monosaccharides in honey [77]. However, some limitations have been described in its application for the removal of certain carbohydrates such as lactose, and also, the presence of some metabolic products such as ethanol, if produced in high amounts, can inhibit the action of yeast [78].

\section{Conclusions and future perspectives}

Nowadays, it is available a great deal of scientific background supporting the advantages of green advanced techniques (MAE, UAE, PLE, etc.) as compared to conventional procedures for the extraction of bioactive carbohydrates from natural sources (Table 2). Moreover, and with the aim of providing an improved performance over these techniques, a variety of new developments have recently emerged. In addition to other advantageous approaches based on the combination of different techniques (e.g. UMAE, MAATPE, UAEE, etc.), it is worth mentioning as a probable way of evolution the use of green solvents (DES, NADES, etc.) in combination with advanced techniques to achieve a better and more selective extraction, while fulfilling the principles of sustainability (recycling, low toxicity, low energy consumption, etc.) of green analytical chemistry. However, further investigation should still be carried out to overcome the limitations of these methodologies for fractionation of bioactive 
436 carbohydrates, which is at present the bottleneck either for their analytical 437 characterization or for their intended use as functional ingredients particularly in the 438 case of specialized foods (e.g. ingredients for diabetics or lactose intolerants, etc.).

439 On the other hand, technological advances regarding equipment design, especially at 440 industrial scale, are still required and will contribute to a great extent to enlarge the 441 application of these methodologies in different fields. Finally, a better understanding of 442 the mechanisms behind these recently developed extraction approaches will also be 443 crucial to reinforce their use as cost-efficient and environmentally friendly technologies 444 to obtain extracts rich in carbohydrates and with improved bioactivity.

\section{Acknowledgements}

446 This work has been funded by Ministerio de Economía, Industria y Competitividad 447 (project AGL2016-80475-R, AEI/FEDER, UE) and by the Comunidad of Madrid and 448 European funding from FSE and FEDER programs (project S2018/BAA-4393, 449 AVANSECAL-II-CM).

\section{LEGENDS OF FIGURES}

Figure 1. Scheme of the selective fractionation of lactulose obtained from lactose 453 isomerization by using [EMIM][DCA] IL and further recycling of this IL using 454 activated charcoal (Reprinted with permission from Carrero-Carralero et al. [11]).

455 Figure 2. Simultaneous extraction/fractionation of homo- and heteropolysaccharides from S. cassia by MAATPE (Reprinted with permission from Chen et al. [40]). 
457 Figure 3. The effect of the temperature (a), time (b), liquid-to-solid ratio (c) and 458 pressure (d) on the extraction yield of polysaccharides from Lycium barbarum L. (LBP) 459 (Reprinted with permission from Chao et al. [49]). 


\section{REFERENCES}

462 [1] P. Markowiak, K. Śliżewska, Effects of Probiotics, Prebiotics, and Synbiotics on Human Health, Nutr. 9 (2017). doi:10.3390/nu9091021.

464 [2] S. Rodríguez-Sánchez, L. Ruiz-Aceituno, M.L. Sanz, A.C. Soria, New Methodologies for the Extraction and Fractionation of Bioactive Carbohydrates from Mulberry (Morus alba) Leaves, J. Agric. Food Chem. 61 (2013) 45394545. doi:10.1021/jf305049k.

[3] M.L. Croze, R.E. Vella, N.J. Pillon, H.A. Soula, L. Hadji, M. Guichardant, C.O. Soulage, Chronic treatment with myo-inositol reduces white adipose tissue accretion and improves insulin sensitivity in female mice, J. Nutr. Biochem. 24 (2013) 457-466. doi:10.1016/j.jnutbio.2012.01.008.

[4] J. Liu, S. Willför, C. Xu, A review of bioactive plant polysaccharides: Biological activities, functionalization, and biomedical applications, Bioact. Carbohydrates Diet. Fibre. 5 (2015) 31-61. doi:10.1016/J.BCDF.2014.12.001.

[5] F.J. Moreno, C. Carrero-Carralero, O. Hernández-Hernández, M.L. Sanz, Fractionation of food bioactive oligosaccharides, in: F.J. Moreno, M.L. Sanz (Eds.), Food Oligosaccharides Prod. Anal. Bioactivity, Wiley-Blackwell, 2014: p.

[6] F. Montañés, T. Fornari, P.J. Martín-Álvarez, A. Montilla, N. Corzo, A. Olano, E. Ibáñez, Selective fractionation of disaccharide mixtures by supercritical $\mathrm{CO}_{2}$ with ethanol as co-solvent, J. Supercrit. Fluids. 41 (2007) 61-67. doi:10.1016/j.supflu.2006.08.010. 
in the food industry?, Trends Food Sci. Technol. 66 (2017) 117-124. doi:10.1016/j.tifs.2017.06.002.

[8] M.E. Zakrzewska, E. Bogel-Łukasik, R. Bogel-Łukasik, Solubility of Carbohydrates in Ionic Liquids, Energy \& Fuels. 24 (2010) 737-745. doi:10.1021/ef901215m.

[9] A.P. Carneiro, C. Held, O. Rodríguez, G. Sadowski, E.A. Macedo, Solubility of Sugars and Sugar Alcohols in Ionic Liquids: Measurement and PC-SAFT Modeling, J. Phys. Chem. B. 117 (2013) 9980-9995. doi:10.1021/jp404864c.

[10] C. Carrero-Carralero, L. Ruiz-Aceituno, L. Ramos, F.J. Moreno, M.L. Sanz, Influence of chemical structure on the solubility of low molecular weight carbohydrates in room temperature ionic liquids, Ind. Eng. Chem. Res. 53 (2014) 13843-13850. doi:10.1021/ie502089j.

[11] C. Carrero-Carralero, L. Ruiz-Aceituno, L. Ramos, M.L. Sanz, F.J. Moreno, Use of room temperature ionic liquids for the selective fractionation of bioactive ketoses from aldoses, Sep. Purif. Technol. 149 (2015) 140-145. doi:10.1016/j.seppur.2015.05.016.

[12] L. Ruiz-Aceituno, C. Carrero-Carralero, L. Ramos, M.L. Sanz, Selective fractionation of sugar alcohols using ionic liquids, Sep. Purif. Technol. 209 (2019) 800-805. doi:10.1016/j.seppur.2018.09.026.

[13] Y. Dai, J. Van Spronsen, G.J. Witkamp, R. Verpoorte, Y.H. Choi, Ionic liquids and deep eutectic solvents in natural products research: Mixtures of solids as extraction solvents, J. Nat. Prod. 76 (2013) 2162-2173. doi:10.1021/np400051w.

[14] L. Ruiz-Aceituno, M.L. Sanz, L. Ramos, Use of ionic liquids in analytical sample 
preparation of organic compounds from food and environmental samples, TrAC Trends Anal. Chem. 43 (2013) 121-145. doi:10.1016/J.TRAC.2012.12.006.

[15] M.C. Bubalo, K. Radošević, I.R. Redovniković, I. Slivac, V.G. Srček, Toxicity mechanisms of ionic liquids, Arch. Ind. Hyg. Toxicol. 68 (2017) 171-179. doi:10.1515/aiht-2017-68-2979.

[16] A.P. Abbott, D. Boothby, G. Capper, D.L. Davies, R.K. Rasheed, Deep Eutectic Solvents Formed between Choline Chloride and Carboxylic Acids: Versatile Alternatives to Ionic Liquids, J. Am. Chem. Soc. 126 (2004) 9142-9147. doi:10.1021/ja048266j.

[17] Y.P. Mbous, M. Hayyan, W.F. Wong, C.Y. Looi, M.A. Hashim, Unraveling the cytotoxicity and metabolic pathways of binary natural deep eutectic solvent systems, Sci. Rep. 7 (2017) 1-14. doi:10.1038/srep41257.

[18] K.D.O. Vigier, G. Chatel, F. Jérôme, Contribution of deep eutectic solvents for biomass processing: Opportunities, challenges, and limitations, ChemCatChem. 7 (2015) 1250-1260. doi:10.1002/cctc.201500134.

[19] A. Satlewal, R. Agrawal, S. Bhagia, J. Sangoro, A.J. Ragauskas, Natural deep eutectic solvents for lignocellulosic biomass pretreatment: Recent developments, challenges and novel opportunities, Biotechnol. Adv. 36 (2018) 2032-2050. doi:10.1016/j.biotechadv.2018.08.009.

[20] M. Francisco, A. van den Bruinhorst, M.C. Kroon, New natural and renewable low transition temperature mixtures (LTTMs): screening as solvents for lignocellulosic biomass processing, Green Chem. $14 \quad$ (2012) 2153. doi:10.1039/c2gc35660k. 
[21] A.C. Soria, M. Villamiel, Effect of ultrasound on the technological properties and bioactivity of food: a review, Trends Food Sci. Technol. 21 (2010) 323-331. doi:10.1016/j.tifs.2010.04.003.

[22] L. Sun, C. Bao, W. Chang, Y. Zhuang, Preparation, characterisation, antioxidant and antiglycation activities of the novel polysaccharides from the pileus of Dictyophora rubrovolvata, Int. J. Food Sci. Technol. 52 (2017) 161-170. doi:10.1111/ijfs.13262.

[23] Q. Kang, S. Chen, S. Li, B. Wang, X. Liu, L. Hao, J. Lu, Comparison on characterization and antioxidant activity of polysaccharides from Ganoderma lucidum by ultrasound and conventional extraction, Int. J. Biol. Macromol. 124 (2019) 1137-1144. doi:10.1016/j.ijbiomac.2018.11.215.

[24] T. Lin, Y. Liu, C. Lai, T. Yang, J. Xie, Y. Zhang, The effect of ultrasound assisted extraction on structural composition, antioxidant activity and immunoregulation of polysaccharides from Ziziphus jujuba Mill var. spinosa seeds, Ind. Crops Prod. 125 (2018) 150-159. doi:10.1016/j.indcrop.2018.08.078.

[25] I. Pawlaczyk-Graja, S. Balicki, K.A. Wilk, Effect of various extraction methods on the structure of polyphenolic-polysaccharide conjugates from Fragaria vesca L. leaf, Int. J. Biol. Macromol. $130 \quad$ (2019) 664-674. doi:10.1016/j.ijbiomac.2019.03.013.

[26] B. Dong, X. Yuan, Q. Zhao, Q. Feng, B. Liu, Y. Guo, B. Zhao, Ultrasoundassisted aqueous two-phase extraction of phenylethanoid glycosides from Cistanche deserticola Y. C. Ma stems, J. Sep. Sci. 38 (2015) 1194-1203. doi:10.1002/jssc. 201401410 .

[27] R. Hao, J. Ma, K. Li, C. Zhu, X. Zhang, Aqueous Two-Phase System Combined 
with Ultrasound for the Extraction Of Polysaccharide from Hawthorn (Crataegus pinnatifida) Leaves, in: Proc. 2nd Int. Conf. Biomed. Biol. Eng. 2017 (BBE 2017), Atlantis Press, Paris, France, 2017. doi:10.2991/bbe-17.2017.37.

[28] X. Ji, Q. Peng, Y. Yuan, F. Liu, M. Wang, Extraction and physicochemical properties of polysaccharides from Ziziphus jujuba cv. Muzao by ultrasoundassisted aqueous two-phase extraction, Int. J. Biol. Macromol. 108 (2018) 541549. doi:10.1016/J.IJBIOMAC.2017.12.042.

[29] L. Zhang, M. Wang, Optimization of deep eutectic solvent-based ultrasoundassisted extraction of polysaccharides from Dioscorea opposita Thunb, Int. J. Biol. Macromol. 95 (2017) 675-681. doi:10.1016/j.ijbiomac.2016.11.096.

[30] H. Zhang, X. Yang, Y. Wang, Microwave assisted extraction of secondary metabolites from plants : Current status and future directions, Trends Food Sci. Technol. 22 (2011) 672-688. doi:10.1016/j.tifs.2011.07.003.

[31] Y. Li, M. Radoiu, A.-S. Fabiano-Tixier, F. Chemat, From Laboratory to Industry: Scale-Up, Quality, and Safety Consideration for Microwave-Assisted Extraction, in: Microwave-Assisted Extr. Bioact. Compd. Theory Pract., 2013. doi:10.1007/978-1-4614-4830-3.

[32] D.-L. Su, P.-J. Li, S. Young Quek, Z.-Q. Huang, Y.-J. Yuan, G.-Y. Li, Y. Shan, Efficient extraction and characterization of pectin from orange peel by a combined surfactant and microwave assisted process, Food Chem. (2019). doi:10.1016/J.FOODCHEM.2019.01.200.

[33] Y. Yuan, X. Xu, C. Jing, P. Zou, C. Zhang, Y. Li, Microwave assisted hydrothermal extraction of polysaccharides from Ulva prolifera: Functional properties and bioactivities, Carbohydr. Polym. 181 (2018) 902-910. 
579

580

581

582

583

584

585

586

587

588

589

590

591

592

593

594

595

596

597

598

599

600

601

[34] L. Ruiz-Aceituno, M.J. García-Sarrió, B. Alonso-rodriguez, L. Ramos, M.L. Sanz, Extraction of bioactive carbohydrates from artichoke (Cynara scolymus L.) external bracts using microwave assisted extraction and pressurized liquid extraction, Food Chem. 196 (2016) 1156-1162.

[35] C. Carrero-Carralero, D. Mansukhani, A.I. Ruiz-Matute, I. Martínez-Castro, L. Ramos, M.L. Sanz, Extraction and characterization of low molecular weight bioactive carbohydrates from mung bean (Vigna radiata), Food Chem. 266 (2018) 146-154. doi:10.1016/J.FOODCHEM.2018.05.114.

[36] S.S. Ferreira, C.P. Passos, S.M. Cardoso, D.F. Wessel, M.A. Coimbra, Microwave assisted dehydration of broccoli by-products and simultaneous extraction of bioactive compounds, Food Chem. 246 (2018) 386-393. doi:10.1016/J.FOODCHEM.2017.11.053.

[37] S.Q. Liew, G.C. Ngoh, R. Yusoff, W.H. Teoh, Sequential ultrasound-microwave assisted acid extraction (UMAE) of pectin from pomelo peels, Int. J. Biol. Macromol. 93 (2016) 426-435. doi:10.1016/J.IJBIOMAC.2016.08.065.

[38] X. Lu, Z. Zheng, H. Li, R. Cao, Y. Zheng, H. Yu, J. Xiao, S. Miao, B. Zheng, Optimization of ultrasonic-microwave assisted extraction of oligosaccharides from lotus (Nelumbo nucifera Gaertn.) seeds, Ind. Crops Prod. 107 (2017) 546557. doi:10.1016/j.indcrop.2017.05.060.

[39] Y. Jiang, X. Bai, S. Lang, Y. Zhao, C. Liu, L. Yu, Optimization of ultrasonicmicrowave assisted alkali extraction of arabinoxylan from the corn bran using response surface methodology, Int. J. Biol. Macromol. 128 (2019) 452-458. doi:10.1016/J.IJBIOMAC.2019.01.138. 
[40] Z. Chen, W. Zhang, X. Tang, H. Fan, X. Xie, Q. Wan, X. Wu, J.Z. Tang, Extraction and characterization of polysaccharides from Semen Cassiae by microwave-assisted aqueous two-phase extraction coupled with spectroscopy and HPLC, Carbohydr. Polym. $144 \quad$ (2016) 263-270. doi:10.1016/J.CARBPOL.2016.02.063.

[41] Z. Cheng, H. Song, X. Cao, Q. Shen, D. Han, F. Zhong, H. Hu, Y. Yang, Simultaneous extraction and purification of polysaccharides from Gentiana scabra Bunge by microwave-assisted ethanol-salt aqueous two-phase system, Ind. Crops Prod. 102 (2017) 75-87. doi:10.1016/J.INDCROP.2017.03.029.

[42] K. Ameer, H.M. Shahbaz, J. Kwon, Green Extraction Methods for Polyphenols from Plant Matrices and Their Byproducts: A Review, Compr. Rev. Food Sci. Food Saf. 16 (2017) 295-315. doi:10.1111/1541-4337.12253.

[43] H. Al-Suod, I.A. Ratiu, R. Górecki, B. Buszewski, Pressurized liquid extraction of cyclitols and sugars: optimization of extraction parameters and selective separation, J. Sep. Sci. (2019) 1-8. doi:10.1002/jssc.201801269.

[44] H. Al-Suod, R. Gadzała-Kopciuch, B. Buszewski, Simultaneous HPLC-ELSD determination of sugars and cyclitols in different parts of Phacelia tanacetifolia Benth., Biochem. Syst. Ecol. 80 (2018) 32-38. doi:10.1016/J.BSE.2018.06.003.

[45] I.-A. Ratiu, H. Al-Suod, M. Ligor, T. Ligor, V. Railean-Plugaru, B. Buszewski, Complex investigation of extraction techniques applied for cyclitols and sugars isolation from different species of Solidago genus, Electrophoresis. 39 (2018) 1966-1974. doi:10.1002/elps.201700419.

[46] L. Ruiz-Aceituno, S. Rodríguez-Sánchez, J. Sanz, M.L. Sanz, L. Ramos, Optimization of pressurized liquid extraction of inositols from pine nuts (Pinus 
$\begin{array}{lllll}\text { pinea } & \text { L.), } & \text { Food } & \text { Chem. } & 153 \quad \text { (2014) }\end{array}$ doi:10.1016/j.foodchem.2013.12.079.

628

[47] R. Vardanega, P.I.N. Carvalho, D.T. Santos, M.A.A. Meireles, Obtaining prebiotic carbohydrates and beta-ecdysone from Brazilian ginseng by subcritical water extraction, Innov. Food Sci. Emerg. Technol. 42 (2017) 73-82. doi:10.1016/J.IFSET.2017.05.007.

[48] F.R. Smiderle, D. Morales, A. Gil-Ramírez, L.I. de Jesus, B. Gilbert-López, M. Iacomini, C. Soler-Rivas, Evaluation of microwave-assisted and pressurized liquid extractions to obtain $\beta$-d-glucans from mushrooms, Carbohydr. Polym. 156 (2017) 165-174. doi:10.1016/J.CARBPOL.2016.09.029.

[49] Z. Chao, Y. Ri-fu, Q. Tai-qiu, Ultrasound-enhanced subcritical water extraction of polysaccharides from Lycium barbarum L., Sep. Purif. Technol. 120 (2013) 141-147. doi:10.1016/J.SEPPUR.2013.09.044.

[50] M. Castro-Puyana, M.L. Marina, M. Plaza, Water as green extraction solvent: Principles and reasons for its use, Curr. Opin. Green Sustain. Chem. 5 (2017) 3136. doi:10.1016/j.cogsc.2017.03.009.

[51] S. Sarkar, V.H. Alvarez, M.D.A. Saldaña, Relevance of ions in pressurized fluid extraction of carbohydrates and phenolics from barley hull, J. Supercrit. Fluids. 93 (2014) 27-37. doi:10.1016/J.SUPFLU.2014.04.019.

[52] P.S. Saravana, Y.-N. Cho, H.-C. Woo, B.-S. Chun, Green and efficient extraction of polysaccharides from brown seaweed by adding deep eutectic solvent in subcritical water hydrolysis, J. Clean. Prod. 198 (2018) 1474-1484. doi:10.1016/J.JCLEPRO.2018.07.151. 
[53] A.I. Ruiz-Matute, M.L. Sanz, N. Corzo, P.J. Martín-Álvarez, E. Ibáñez, I. Martínez-Castro, A. Olano, Purification of lactulose from mixtures with lactose using pressurized liquid extraction with ethanol-water at different temperatures, J. Agric. Food Chem. 55 (2007) 3346-3350. doi:10.1021/jf070018u.

[54]A.I. Ruiz-Matute, L. Ramos, I. Martínez-Castro, M.L. Sanz, Fractionation of honey carbohydrates using pressurized liquid extraction with activated charcoal, J. Agric. Food Chem. 56 (2008) 8309-8313. doi:10.1021/jf8014552.

[55] A.T. Getachew, Y.J. Cho, B.S. Chun, Effect of pretreatments on isolation of bioactive polysaccharides from spent coffee grounds using subcritical water, Int. J. Biol. Macromol. 109 (2018) 711-719. doi:10.1016/J.IJBIOMAC.2017.12.120.

[56] F. Montañés, T. Fornari, P.J. Martín-Álvarez, N. Corzo, A. Olano, E. Ibáñez, Selective recovery of tagatose from mixtures with galactose by direct extraction with supercritical CO2 and different cosolvents, J. Agric. Food Chem. 54 (2006) 8340-8345. doi:10.1021/jf0618123.

[57] F. Montañés, N. Corzo, A. Olano, G. Reglero, E. Ibáñez, T. Fornari, Selective fractionation of carbohydrate complex mixtures by supercritical extraction with $\mathrm{CO}_{2}$ and different co-solvents, J. Supercrit. Fluids. 45 (2008) 189-194. doi:10.1016/j.supflu.2007.08.012.

[58] F. Montañés, A. Olano, G. Reglero, E. Ibáñez, T. Fornari, Supercritical technology as an alternative to fractionate prebiotic galactooligosaccharides, Sep. Purif. Technol. 66 (2009) 383-389. doi:10.1016/j.seppur.2008.12.006.

[59] F. Montañés, T. Fornari, A. Olano, E. Ibáñez, Supercritical fluid purification of complex carbohydrate mixtures produced by enzimatic transglycosylation and isomerized with complexating reagents, J. Supercrit. Fluids. 53 (2010) 25-33. 
doi:10.1016/j.supflu.2010.02.011.

674

675

676

677

678

679

680

681

682

683

684

685

686

687

688

689

690

691

692

693

694

695

[60] J. Chen, J. Li, A. Sun, B. Zhang, S. Qin, Y. Zhang, Supercritical CO2 extraction and pre-column derivatization of polysaccharides from Artemisia sphaerocephala Krasch. seeds via gas chromatography, Ind. Crops Prod. 60 (2014) 138-143. doi:10.1016/J.INDCROP.2014.06.013.

[61] X. Zou, Y. Liu, C. Tao, Y. Liu, M. Liu, J. Wu, Z. Lv, CO2 supercritical fluid extraction and characterization of polysaccharide from bamboo (Phyllostachys heterocycla) leaves, J. Food Meas. Charact. $12 \quad$ (2018) 35-44. doi:10.1007/s11694-017-9614-2.

[62] S.S. Nadar, P. Rao, V.K. Rathod, Enzyme assisted extraction of biomolecules as an approach to novel extraction technology: A review, Food Res. Int. 108 (2018) 309-330. doi:10.1016/j.foodres.2018.03.006.

[63] L. Sun, D. Wu, X. Ning, G. Yang, Z. Lin, M. Tian, Y. Zhou, $\alpha$-Amylase-assisted extraction of polysaccharides from Panax ginseng, Int. J. Biol. Macromol. 75 (2015) 152-157. doi:10.1016/J.IJBIOMAC.2015.01.025.

[64] Y.M. Zhao, J.H. Song, J. Wang, J.M. Yang, Z.B. Wang, Y.H. Liu, Optimization of cellulase-assisted extraction process and antioxidant activities of polysaccharides from Tricholoma mongolicum Imai, J. Sci. Food Agric. 96 (2016) 4484-4491. doi:10.1002/jsfa.7662.

[65] Y. Chen, F. Yao, K. Ming, D. Wang, Y. Hu, J. Liu, Polysaccharides from Traditional Chinese Medicines: Extraction, Purification, Modification, and Biological Activity, $\quad$ Molecules. $\quad 21 \quad$ (2016) 1705. doi:10.3390/molecules21121705. 
[66] S. Chen, H. Chen, J. Tian, J. Wang, Y. Wang, L. Xing, Enzymolysis-ultrasonic assisted extraction, chemical characteristics and bioactivities of polysaccharides from corn silk, Carbohydr. Polym. $101 \quad$ (2014) 332-341. doi:10.1016/j.carbpol.2013.09.046.

[67] J. H. Lee, H. H. Kim, J. Y. Ko, J. H. Jang, G. H. Kim, J. S. Lee, J. W. Nah, Y. J. Jeon, Rapid preparation of functional polysaccharides from Pyropia yezoensis by microwave-assistant rapid enzyme digest system, Carbohydr. Polym. 153 (2016) 512-517. doi:10.1016/J.CARBPOL.2016.07.122.

[68] R.M. Wahlström, A. Suurnäkki, Enzymatic hydrolysis of lignocellulosic polysaccharides in the presence of ionic liquids, Green Chem. 17 (2015) 694714. doi:10.1039/c4gc01649a.

[69] J. Liang, Y. Zeng, H. Wang, W. Lou, Extraction, purification and antioxidant activity of novel polysaccharides from Dendrobium officinale by deep eutectic solvents, Nat. Prod. Res. 6419 (2018) 1-6. doi:10.1080/14786419.2018.1471480.

[70] B. Splechtna, I. Petzelbauer, U. Baminger, D. Haltrich, K.D. Kulbe, B. Nidetzky, Production of a lactose-free galacto-oligosaccharide mixture by using selective enzymatic oxidation of lactose into lactobionic acid, Enzyme Microb. Technol. 29 (2001) 434-440. doi:10.1016/S0141-0229(01)00412-4.

[71] R. Crittenden, M. Playne, Purification of food-grade oligosaccharides using immobilised cells of Zymomonas mobilis, Appl. Microbiol. Biotechnol. 58 (2002) 297-302. doi:10.1007/s00253-001-0886-3.

[72] L.F.M.C. Aquino, J.M.L.N. de Moura Bell, J.L. Cohen, Y. Liu, H. Lee, V.L. de Melo Silva, P. Domizio, C.A. Conte Junior, D. Barile, Purification of caprine oligosaccharides at pilot-scale, J. Food Eng. 214 (2017) 226-235. 
doi:10.1016/j.jfoodeng.2017.06.009.

721

722

[73] A.I. Ruiz-Matute, M. Corzo-Martínez, A. Montilla, A. Olano, P. Copovi, N. Corzo, Presence of mono-, di- and galactooligosaccharides in commercial lactose-free UHT dairy products, J. Food Compos. Anal. 28 (2012) 164-169. doi:10.1016/J.JFCA.2012.06.003.

[74] C. Guerrero, C. Vera, C. Novoa, J. Dumont, F. Acevedo, A. Illanes, Purification of highly concentrated galacto-oligosaccharide preparations by selective fermentation with yeasts, Int. Dairy J. 39 (2014) 78-88. doi:10.1016/j.idairyj.2014.05.011.

[75] C. Nobre, C.C. Castro, A.L. Hantson, J.A. Teixeira, G. De Weireld, L.R. Rodrigues, Strategies for the production of high-content fructo-oligosaccharides through the removal of small saccharides by co-culture or successive fermentation with yeast, Carbohydr. Polym. $136 \quad$ (2016) 274-281. doi:10.1016/j.carbpol.2015.08.088.

[76] L. Ruiz-Aceituno, S. Rodríguez-Sánchez, A.I. Ruiz-Matute, L. Ramos, A.C. Soria, M.L. Sanz, Optimisation of a biotechnological procedure for selective fractionation of bioactive inositols in edible legume extracts, J. Sci. Food Agric. 93 (2013) 2797-2803. doi:10.1002/jsfa.6103.

[77] A.I. Ruiz-Matute, A.C. Soria, I. Martínez-Castro, M.L. Sanz, A New Methodology Based on GC-MS To Detect Honey Adulteration with Commercial Syrups, J. Agric. Food Chem. 55 (2007) 7264-7269. doi:10.1021/jf070559j.

[78] A. Goulas, G. Tzortzis, G.R. Gibson, Development of a process for the production and purification of $\alpha$ - and $\beta$-galactooligosaccharides from Bifidobacterium bifidum NCIMB 41171, Int. Dairy J. 17 (2007) 648-656. 

doi:10.1016/J.IDAIRYJ.2006.08.010

745 
Figure 1. Mena et al.

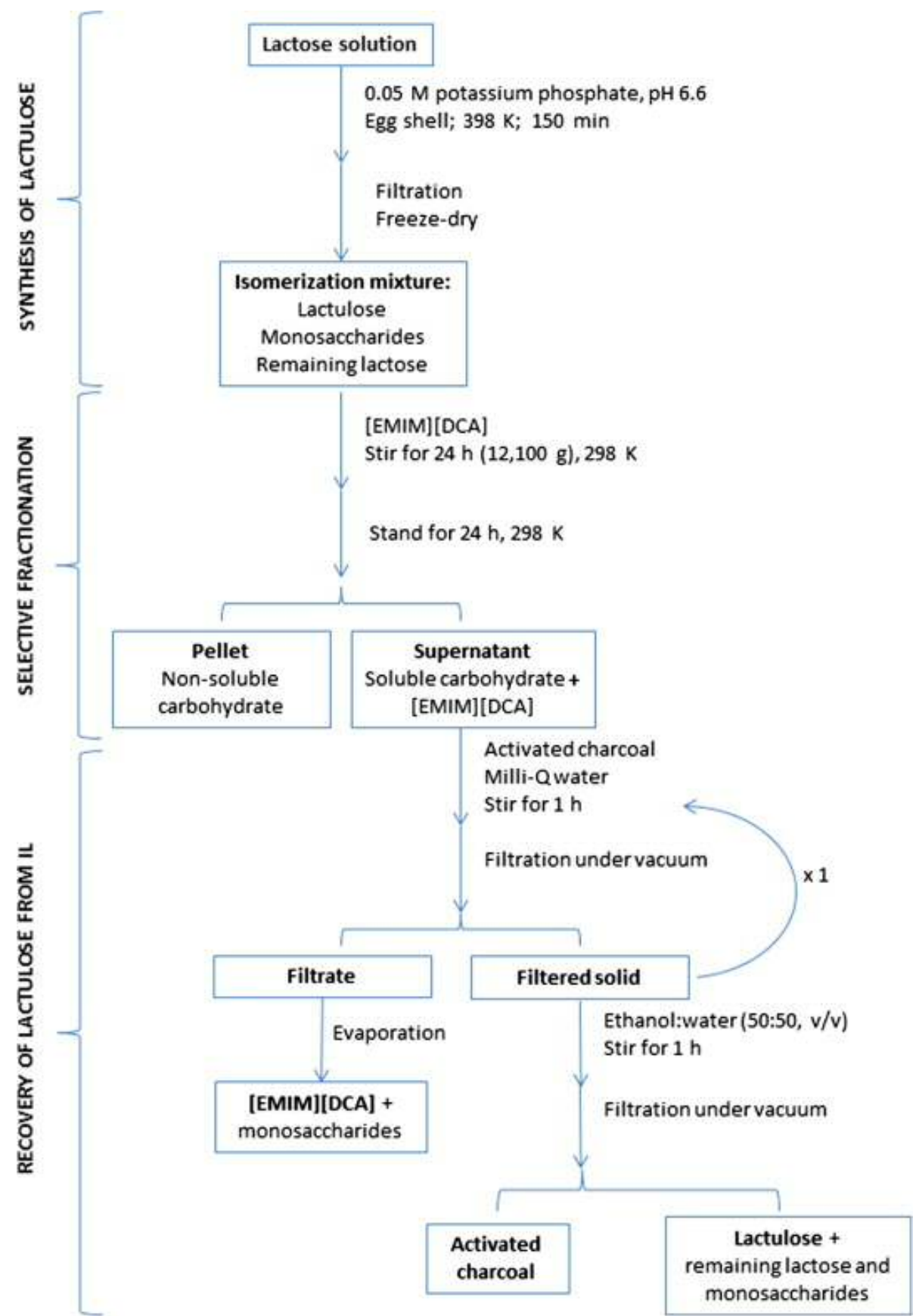


Figure 2.

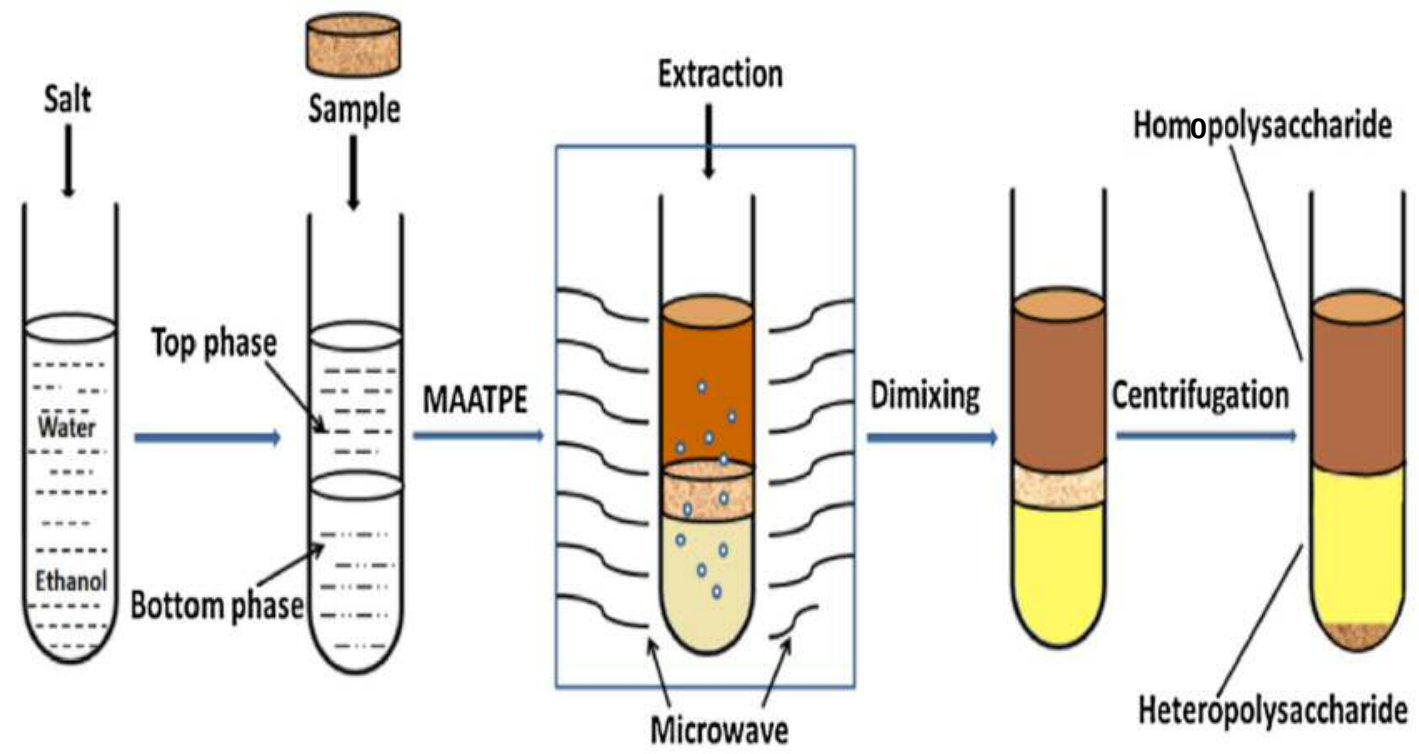


Figure 3. Mena et al.
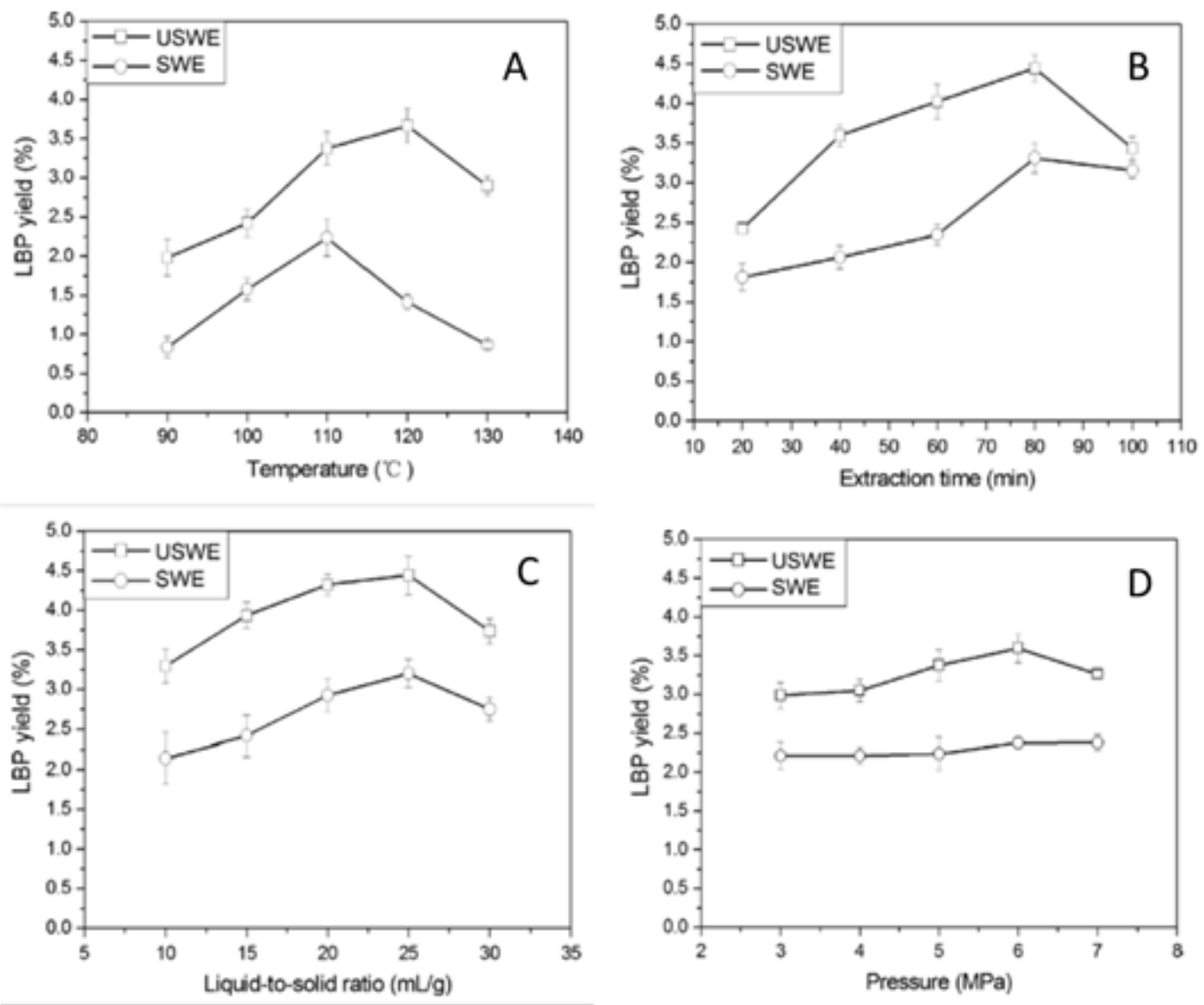
Table 1. Recent applications of green techniques for extraction of bioactive carbohydrates.

\begin{tabular}{|c|c|c|c|c|}
\hline Technique & $\begin{array}{c}\text { Bioactive } \\
\text { carbohydrates }\end{array}$ & Source & Experimental conditions & Ref. \\
\hline $\begin{array}{l}\text { UAE } \\
\text { PLE }\end{array}$ & Polysaccharides & $\begin{array}{l}\text { Ziziphus jujuba Mill } \\
\text { var. spinosa seeds }\end{array}$ & $\begin{array}{l}\mathrm{H}_{2} \mathrm{O}, 26.3 \mathrm{~mL} \mathrm{~g}^{-1}, 52.5^{\circ} \mathrm{C}, 21.2 \mathrm{~min}, 134.9 \mathrm{~W} \\
\mathrm{H}_{2} \mathrm{O}, 7.5 \mathrm{~mL} \mathrm{~g}^{-1}, 70^{\circ} \mathrm{C}, 3 \mathrm{~h}, 2 \text { cycles }\end{array}$ & {$[24]$} \\
\hline UAATPE & Polysaccharides & $\begin{array}{l}\text { Z. jujuba cv. Muzao } \\
\text { fruits }\end{array}$ & $29 \% \mathrm{EtOH} / 15 \%\left(\mathrm{NH}_{4}\right)_{2} \mathrm{SO}_{4}, 30 \mathrm{~mL} \mathrm{~g}^{-1}, 48^{\circ} \mathrm{C}, 38 \mathrm{~min}, 70 \mathrm{~W}$ & {$[28]$} \\
\hline UAE & Polysaccharides & $\begin{array}{l}\text { Dioscorea opposite } \\
\text { Thunb. }\end{array}$ & Choline chloride-DES with $33 \% \mathrm{H}_{2} \mathrm{O}, 30 \mathrm{~mL} \mathrm{~g}^{-1}, 94^{\circ} \mathrm{C}, 45 \mathrm{~min}$ & [29] \\
\hline $\begin{array}{l}\text { MAE } \\
\text { S-MAE }\end{array}$ & Pectin & Orange peel & $\begin{array}{l}0.1 \mathrm{M} \mathrm{HCl}(\mathrm{pH}: 1.2), 21.5 \mathrm{~mL} \mathrm{~g}^{-1}, 7 \mathrm{~min}, 400 \mathrm{~W} \\
\text { Surfactant: Tween- } 808 \mathrm{~g} \mathrm{~L}^{-1}\end{array}$ & [32] \\
\hline $\begin{array}{l}\text { MAE } \\
\text { PLE }\end{array}$ & Inulin and inositols & Artichoke & $\begin{array}{l}\mathrm{H}_{2} \mathrm{O}, 0.03 \mathrm{~g} \mathrm{~mL}^{-1}, 60^{\circ} \mathrm{C}, 3 \mathrm{~min}, 2 \text { cycles, } 900 \mathrm{~W} \\
\mathrm{H}_{2} \mathrm{O}, 0.03 \mathrm{~g} \mathrm{~mL}^{-1}, 75^{\circ} \mathrm{C}, 26.7 \mathrm{~min}, 2 \text { cycles, } 10 \mathrm{MPa}\end{array}$ & {$[34]$} \\
\hline MAE & $\alpha$-GOS and inositols & Mung bean & $\mathrm{H}_{2} \mathrm{O}: \mathrm{EtOH}(1: 1), 0.055 \mathrm{~g} \mathrm{~mL}^{-1}, 50^{\circ} \mathrm{C}, 3 \mathrm{~min}, 2$ cycles, $1250 \mathrm{~W}$ & {$[35]$} \\
\hline MHG & $\begin{array}{l}\text { Glucosinolates and } \\
\text { other bioactive } \\
\text { compounds }\end{array}$ & Broccoli by-products & Solvent-free, $550 \mathrm{~g}, 37-43 \mathrm{~min}, 500 \mathrm{~W}$ & {$[36]$} \\
\hline $\begin{array}{l}\text { UAE+MAE } \\
\text { MAE+UAE } \\
\text { MAE } \\
\text { UAE }\end{array}$ & Pectin & Pomelo peels & $\begin{array}{l}\mathrm{H}_{2} \mathrm{O} \mathrm{pH}: 1.80 \text { (citric acid, } 0.3 \mathrm{~g} \mathrm{~mL}^{-1} \text { ), } 27.52 \mathrm{~min} \text { (UAE), } 6.40 \mathrm{~min} \\
\text { and } 643.44 \mathrm{~W} \text { (MAE) }\end{array}$ & [37] \\
\hline UMAE & Oligosaccharides & Lotus seeds & $\mathrm{H}_{2} \mathrm{O}, 10 \mathrm{~mL} \mathrm{~g}^{-1}, 325 \mathrm{~s}, 300 \mathrm{~W}$ (US), $250 \mathrm{~W}(\mathrm{MW})$ & {$[38]$} \\
\hline
\end{tabular}




\begin{tabular}{|c|c|c|c|c|}
\hline UMAE & $\begin{array}{l}\text { Water-unextractable } \\
\text { arabinoxylan } \\
\text { (WUAX) }\end{array}$ & Corn bran & $0.30 \mathrm{M} \mathrm{NaOH}, 30 \mathrm{~mL} \mathrm{~g}^{-1}, 70^{\circ} \mathrm{C}, 25 \mathrm{~min}, 500 \mathrm{~W}$ & [39] \\
\hline $\begin{array}{l}\text { MAATPE } \\
\text { MAE } \\
\text { UAE }\end{array}$ & Polysaccharides & Gentiana scabra & $\begin{array}{l}\mathrm{H}_{2} \mathrm{O}, 21.73 \% \mathrm{EtOH} ; 23.27 \% \mathrm{NaH}_{2} \mathrm{PO}_{4}, 21 \mathrm{~mL} \mathrm{~g}^{-1}, 95^{\circ} \mathrm{C}, 5.8 \mathrm{~min}, \\
800 \mathrm{~W} \\
\mathrm{H}_{2} \mathrm{O}, 27 \mathrm{~mL} \mathrm{~g}^{-1}, 100^{\circ} \mathrm{C}, 4 \mathrm{~min}, 500 \mathrm{~W} \\
\mathrm{H}_{2} \mathrm{O}, 60 \mathrm{~mL} \mathrm{~g}^{-1}, 50^{\circ} \mathrm{C}, 60 \mathrm{~min}, 180 \mathrm{~W}\end{array}$ & {$[41]$} \\
\hline PLE & Cyclitols and sugars & Alfalfa & $\mathrm{H}_{2} \mathrm{O}, 0.5 \mathrm{~g}, 88^{\circ} \mathrm{C}, 22 \mathrm{~min}, 2$ cycles & {$[43]$} \\
\hline $\begin{array}{l}\text { PLE } \\
\text { UAE } \\
\text { SFE }\end{array}$ & Cyclitols and sugars & Goldenrods & $\begin{array}{l}\mathrm{H}_{2} \mathrm{O}, 0.1 \mathrm{~g} \mathrm{~mL}^{-1}, 50^{\circ} \mathrm{C}, 18 \mathrm{~min}, 3 \text { cycles, } 10 \mathrm{MPa} \\
\mathrm{H}_{2} \mathrm{O}, 0.06 \mathrm{~g} \mathrm{~mL}^{-1}, 50^{\circ} \mathrm{C}, 30 \mathrm{~min}, 2 \text { cycles } \\
\mathrm{CO}_{2}\left(4 \mathrm{~mL} \mathrm{~min}^{-1}\right) / 70 \% \text { ethanol }(4: 1), 1 \mathrm{~g}, 50^{\circ} \mathrm{C}, 60 \mathrm{~min}, 10 \mathrm{MPa}\end{array}$ & {$[45]$} \\
\hline PLE & FOS & Brazilian ginseng & $\mathrm{H}_{2} \mathrm{O}, 1.4 \mathrm{~mL} \mathrm{~min}{ }^{-1}, 14 \mathrm{~min}, 119.85^{\circ} \mathrm{C}, 5 \mathrm{~min}, 12 \mathrm{MPa}$ & {$[47]$} \\
\hline $\begin{array}{l}\text { PLE } \\
\text { MAE }\end{array}$ & $\beta$-glucans & Mushrooms & $\begin{array}{l}\mathrm{H}_{2} \mathrm{O}, 0.5 \mathrm{~g}, 180^{\circ} \mathrm{C}, 22-26 \mathrm{~min}, 10.2-11.7 \mathrm{MPa} \\
\mathrm{H}_{2} \mathrm{O}, 0.3 \mathrm{~g} \mathrm{~mL}^{-1}, 180^{\circ} \mathrm{C}, 27-30 \mathrm{~min}, 850 \mathrm{~W}\end{array}$ & {$[48]$} \\
\hline $\begin{array}{l}\text { PLE }+ \text { activated } \\
\text { charcoal }\end{array}$ & Oligosaccharides & Honey & $\begin{array}{l}\text { EtOH: } \mathrm{H}_{2} \mathrm{O}\left(1: 99,1^{\text {st }} \text { cycle; } 50: 50,2^{\text {nd }} \text { cycle }\right), 25 \mathrm{mg} \mathrm{mL}^{-1}, 200 \mathrm{mg} \\
\text { activated charcoal, } 40^{\circ} \mathrm{C}, 5 \mathrm{~min}\left(1^{\text {st }} \text { cycle }\right) \text { and } 10 \mathrm{~min}\left(2^{\text {nd }} \text { cycle }\right) \text {, } \\
10 \mathrm{MPa}\end{array}$ & {$[54]$} \\
\hline SFE & $\begin{array}{l}\text { Mono-, di-,tri- and } \\
\text { tetrasaccharides } \\
\text { fractionation }\end{array}$ & $\begin{array}{c}\text { Commercial GOS } \\
\text { mixture }\end{array}$ & 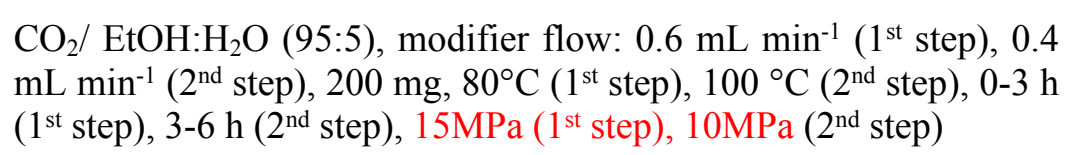 & {$[57]$} \\
\hline
\end{tabular}




\begin{tabular}{|c|c|c|c|c|}
\hline SFE & Oligosaccharides & $\begin{array}{l}\text { Prebiotic synthetic } \\
\text { oligosaccharides } \\
\text { mixtures }\end{array}$ & $\begin{array}{l}\mathrm{CO}_{2} / \text { EtOH: } \mathrm{H}_{2} \mathrm{O}(95: 5)\left(1^{\text {st }} \text { step }\right) \text { and } \mathrm{EtOH}: \mathrm{H}_{2} \mathrm{O}: \mathrm{H}_{2} \mathrm{SO}_{4}(90: 9: 1)\left(2^{\text {nd }}\right. \\
\text { step }) \text {, modifiers flow: } 0.6 \mathrm{~mL} \mathrm{~min}^{-1}\left(1^{\text {st }} \text { step and } 3^{\text {rd }} \text { step }\right), 0.4 \mathrm{~mL} \\
\mathrm{~min}^{-1}\left(2^{\text {nd }} \text { step }\right), 200 \mathrm{mg} \text { mixture, } 80^{\circ} \mathrm{C}\left(1^{\text {st }} s \text { step and } 3^{\text {rd }} \text { step }\right), 100^{\circ} \mathrm{C} \\
\left(2^{\text {nd }} \text { step }\right), 0-3 \mathrm{~h}\left(1^{\text {st }} \text { step }\right), 3-6 \mathrm{~h}\left(2^{\text {nd }} \text { step }\right), 6-9 \mathrm{~h}\left(3^{\text {rd }} \text { step }\right), 15 \mathrm{MPa} \\
\left(1^{\text {st }} \text { step and } 3^{\text {rd }} \text { step }\right), 10 \mathrm{MPa}\left(2^{\text {nd }} \text { step }\right)\end{array}$ & {$[59]$} \\
\hline $\begin{array}{l}\text { EUAE } \\
\text { HWE }\end{array}$ & Polysaccharides & Corn silk & $\begin{array}{l}\mathrm{H}_{2} \mathrm{O} \text {, cellulase } 7.5 \%, 31.8 \mathrm{~mL} \mathrm{~g}^{-1}, 55^{\circ} \mathrm{C}, 150 \min (\mathrm{EAE}), 66.3^{\circ} \mathrm{C}, \\
34.2 \mathrm{~min} \text { (US) } \\
\mathrm{H}_{2} \mathrm{O} ; 0.06 \mathrm{~g} \mathrm{~mL}^{-1}, 100^{\circ} \mathrm{C}, 1 \mathrm{~h}, 3 \text { cycles }\end{array}$ & {$[66]$} \\
\hline MAEE & $\begin{array}{l}\text { Polysaccharide } \\
\text { hydrolysates }\end{array}$ & Pyropia yezoensis & 10:1 substrate:carbohydrase; $2 \mathrm{~h} ; 400 \mathrm{~W}$ & {$[67]$} \\
\hline $\begin{array}{l}\text { DES-based EAE } \\
\text { SDE }\end{array}$ & Polysaccharides & Dendrobium officinale & $\begin{array}{l}\text { DES (choline chloride/glycerol) } / \mathrm{H}_{2} \mathrm{O}, 0.03 \mathrm{~g} \mathrm{~mL}^{-1}, 6 \mathrm{mg} \mathrm{mL}^{-1} \\
\text { cellulase and pectinase, } 55^{\circ} \mathrm{C}, 120 \mathrm{~min} \\
\text { DES(choline chloride/glycerol) } / \mathrm{H}_{2} \mathrm{O}, 0.03 \mathrm{~g} \mathrm{~mL}^{-1}, 55^{\circ} \mathrm{C}, 120 \mathrm{~min}\end{array}$ & {$[69]$} \\
\hline
\end{tabular}

DES: deep eutectic solvents; EAE: enzyme-assisted extraction; HWE: hot water extraction; MAATPE: microwave-assisted aqueous two-phase extraction; MAE: microwave-assisted extraction; MAEE: microwave-assisted enzymatic extraction; MHG: Microwave hydrodiffusion and gravity; PLE: pressurized liquid extraction; SDE: solvent direct extraction; S-MAE: surfactant and microwave-assisted extraction; SFE: supercritical fluid extraction; UAE: ultrasoundassisted extraction; UAATPE: ultrasound-assisted aqueous two-phase extraction; EUAE: enzymolysis-ultrasonic assisted extraction. 
Table 2. Advantages and disadvantages of the main techniques for green extraction of bioactive carbohydrates

\begin{tabular}{|c|c|c|}
\hline Technique & Advantages & Disadvantages \\
\hline Solid-liquid extraction (SLE) & Simplicity & $\begin{array}{l}\text { Long extraction times and limited } \\
\text { extraction efficiency }\end{array}$ \\
\hline $\begin{array}{l}\text { Ultrasound-assisted extraction } \\
\text { (UAE) }\end{array}$ & $\begin{array}{l}\text { Enhancement of extraction efficiency } \\
\text { by cavitation phenomenon } \\
\text { Instrumental setup (baths or probes) }\end{array}$ & $\begin{array}{l}\text { Lack of uniformity in the distribution of US } \\
\text { energy and decline of power with time }\end{array}$ \\
\hline $\begin{array}{l}\text { Microwave-assisted extraction } \\
\text { (MAE) }\end{array}$ & $\begin{array}{l}\text { Heating of solvent by dipole rotation } \\
\text { and ionic conduction: shorter } \\
\text { extraction time and lower energy } \\
\text { consumption, higher extraction yields } \\
\text { Water as the optimal green solvent } \\
\text { for MW heating due to its high } \\
\text { dipolar moment }\end{array}$ & Non homogeneous heating \\
\hline $\begin{array}{l}\text { Pressurized liquid extraction } \\
\text { (PLE) }\end{array}$ & $\begin{array}{c}\text { Improvement of mass transfer } \\
\text { kinetics: shorter extraction times and } \\
\text { higher yields } \\
\text { Modulation of solvent properties } \\
\text { (lower polarity at higher temperature) } \\
\text { SHWE: water as a green solvent with } \\
\text { a wide polarity range }\end{array}$ & System leaks and pipe obstructions \\
\hline $\begin{array}{l}\text { Supercritical fluid extraction } \\
\text { (SFE) }\end{array}$ & $\begin{array}{l}\text { Improvement of extraction } \\
\text { efficiency, shorter production cycles, } \\
\text { greenness. } \\
\mathrm{CO}_{2} \text { easily recovered avoiding } \\
\text { expensive post-processing }\end{array}$ & $\begin{array}{l}\text { Complex equipment, } \\
\text { high capital investment for the setting up } \\
\text { and high operational cost } \\
\text { Barely applied for extraction and } \\
\text { fractionation of carbohydrates }\end{array}$ \\
\hline
\end{tabular}




\begin{tabular}{|c|c|c|}
\hline Enzyme-assisted extraction (EAE) & $\begin{array}{c}\text { Selectivity and mild reaction } \\
\text { conditions, ease of operation, low } \\
\text { investment cost and energy } \\
\text { requirements }\end{array}$ & $\begin{array}{c}\text { Combination of enzymes are usually } \\
\text { required to fully achieve extraction } \\
\text { objectives }\end{array}$ \\
$\begin{array}{c}\text { The presence of inhibitors can affect } \\
\text { enzyme activity }\end{array}$ \\
\hline
\end{tabular}

